\title{
Cursus in Dante Alighieri's prose books De vulgari eloquentia, De Monarchia and Convivio
}

\section{Annika Mikkel*}

\begin{abstract}
This paper examines the prose rhythm in Dante's Latin and Italian prose. The samples of Dante's Latin books De vulgari eloquentia and De Monarchia and the Italian book Convivio are analysed with the purpose of finding the incidence and patterns of prose rhythm. The method used in this paper is comparative-statistical analysis. The rhythm of classic prose was based on the quantity of syllables, while the medieval Latin prose rhythm was based on word stress and called cursus. Although the use of cursus was more popular in Latin prose, it can also be found elsewhere, including Italian prose. The analysis reveals that rhythmical sentences endings have a role in Dante's prose and that the cursus appear in his Latin works, as well as in his works in vernacular.
\end{abstract}

Keywords: prose rhythm, cursus, clausula, Dante

\section{Introduction}

The aim of this paper is to study the prose rhythm in Dante's Latin and Italian prose using the method of comparative-statistical analysis. The term 'prose rhythm' is used in ancient rhetoric to denote rhythmical units at the end of sentences and clauses which in classic prose were called clausulae. The rhythm of classic prose was based on the quantity of syllables. In time, the system of clausulae was simplified and amongst quantity, word stress became significant. Medieval Latin prose rhythm was based exclusively on word stress and called cursus.

Besides Latin prose, cursus can also be found elsewhere, including Italian prose. As regards Dante and the use of cursus in his books in vernacular, there are differences in opinions whether, and to what extent Dante intentionally rhythmicized his clause endings.

In my research I have analysed the occurrence of cursus in Dante's Latin books De vulgari eloquentia and De Monarchia, and the Italian book Convivio

* Author's address: Annika Mikkel, Assistant in Romance Philology, Lossi 3, 51003, Tartu, Estonia.E-mail: annika.mikkel@ut.ee. 
(books I and II) with the purpose of finding the incidence and patterns of prose rhythm ${ }^{1}$. The sample of Latin books was formed from the first ten chapters in both books, and altogether 822 sentence- and clause-ends (474 endings from De vulgari eloquentia and 348 endings from De Monarchia) were analysed. In the case of Convivio, the sample was formed from all the sentenceand clause-ends in the first two books, altogether totalling 2810 endings.

In determining the rhythm schemes some problems of prosody became apparent. The syllabication of Italian words is not problematic when the syllable line is between a vowel and a consonant or between two consonants. But when there are several vowels in a row, the situation is more complicated, because the language then often allows two ways of syllabication (Menichetti 1993: 176-177). The situation is even more complicated when one of the juxtaposed vowels is an unstressed i or $\mathrm{u}$, as in Italian those phonemes could be half-consonants. In case of doubt, Aldo Menichetti suggests to consult the dictionary Dizionario d'ortografia e di pronunzia. This recommendation has been followed within this analysis.

As regards to the Latin, it has been said that in medieval Latin accentuation appears often to be the same as in antiquity (Norberg 1968: 88). Medieval writers had learned their prosody and accentuation from classical models, but still occasional mistakes appear (Strecker 1999: 58, Norberg 2014: 31-49). Thus, for this analysis the rules of accentuation of the classical Latin have been followed.

\section{Prose rhythm}

\subsection{Prose rhythm in ancient prose}

As has been said before, the rhythm of classic prose was based on the quantity of syllables. The use of clausulae is seen, for example, in the works of Cato (De Agri Cultura), Gaius Gracchus, Livy, Sallust and, of course, Cicero. Cicero's preference of certain clausulae is evident. The most common rhythmical units used by Cicero are ${ }^{2}$ :

a. $-\cup-\longrightarrow-/ / \cup \cup-\cup$ (for example, illa tempestas)

cretic, spondee // cretic, trochee

1 I have formerly analysed the occurrence of cursus in Dante's Italian books Vita Nuova (Mikkel 2011).

2 See Grillo 2015: 43-44. 
b. $-\cup--\cup-/ /---\smile \cup-$ (for example, adiutus non debui) cretic, cretic // molossus, cretic c. $-\cup-\longrightarrow \cup-\mathrm{X} / /-\longrightarrow-\cup \cup-\mathrm{X}$ (for example, Caesari de eius actis) cretic, ditrochee // molossus, ditrochee

It has been mentioned that the authors posterior to Cicero heavily preferred his cretic-trochee, dicretic and ditrochee clausulae (Oberhelman, Hall, 1984: 114).

Prose rhythm in the sense of clausulae has been discussed by Cicero mainly in the third book of the De Oratore and in the Orator 168-238. It has been noted how Cicero himself did not favour his recommended clausulae: for example the clausula heroa — $\cup \cup \_$, which seems to have been recommended by him in Or. 217, is quite rare in his extant works; and on the other hand, the "cretic + spondee" sequence (_ $-—-$ ) is used very frequently, but was not mentioned by Cicero in his theoretical discussion of clausulae (Aili 1979: 9).

\subsection{Prose rhythm in medieval Latin prose}

In time, the system of clausulae was simplified and, amongst quantity, word stress became significant. This type of prose rhythm where the clausula is structured both accentually and quantitatively, has been defined by modern scholars as cursus mixtus ${ }^{3}$. The clausula is simultaneously one of the forms of the cursus and one of the standard metrical forms (cretic-spondee, dicretic, cretic-tribrach, ditrochee) (Oberhelman, Hall 1985: 216) ${ }^{4}$. Cursus mixtus, in turn, developed into medieval Latin prose rhythm that was purely based on word stress and was called cursus (Norberg 1968: 87, Clark 1910: 10-11).

There were four different rhythmic patterns in the late Middle Ages: $d$. cursus planus (Xx xXx, for example audíri compéllunt $\left.{ }^{5}\right)$, e. cursus velox (Xxx $\mathrm{xxXx}$, for example gaúdia perveníre), f. cursus tardus ( $\mathrm{Xx} \mathrm{xXxx}$, for example tímet impéria) and g. cursus trispondaicus ( $\mathrm{Xx} \mathrm{xxXx}$, for example dóna sentiámus, which was also treated as the second form of cursus planus). Rhythmical

\footnotetext{
3 See, for example, the articles of Steven M. Oberhelman and Ralph G. Hall $(1984,1985)$ who have analysed the accentual prose rhythms in imperial Latin authors.

4 Oberhelman and Hall bring an example of the clausula missa pervenerit which is a cursus tardus, while metrically it is a dicretic (Oberhelman, Hall 1985: 216).

5 See Norberg 1968: 87.
} 
units comprise at least two words and the last word must have at least three syllables. The number of syllables in the preceding word is not important, only the stress is relevant (Tunberg 1996: 115, Janson 1975: 10).

Comparing the medieval forms of cursus and clausulae used in classic prose, we can see that cursus planus is based on the clausulae "cretic + spondee" (Xx xXx and — $-— —$; for an example, see d. in 2.2 and a. in 2.1), cursus velox is based on the clausulae "cretic + ditrochee" (Xxx $\mathrm{xxXx}$ and $\cup-\_\cup-\mathrm{X}$; for an example, see e. in 2.2 and c. in 2.1), and cursus tardus is based on the clausulae "cretic + cretic" (Xx xXxx and $-\cup-\longrightarrow \cup-$; for an example, see f. in 2.2 and b. in 2.1).

In medieval prose, a rhythm notion of consillabicatio was introduced replacing the last word with two or three short words that include the same number of syllables. Moreover, a different way of describing cursus was used where the length of the last word was not considered important, but only the number of syllables between the last two stresses and after the stress of the last word is observed. Therefore, for example, next to the usual cursus planus are the forms X xxXx and Xxx Xx (Lindholm 1963: 40-51). In Latin prose, cursus velox was the most popular, and used often at the end of the sentences and also at the end of books (Toynbee 1966: 229). According to Toynbee, cursus velox is the most frequent cursus also in Dante's Latin book Letters (Epistolae) (ib. 242).

\section{The occurrence of cursus in Dante}

\subsection{The occurrence of cursus in Dante's Latin books De vulgari eloquentia and De Monarchia}

De vulgari eloquentia is an unfinished book of Dante and was probably composed between 1303 and 1305 (Malato 1999: 873). In the first book Dante discusses the relationship between Latin and vernacular and is searching for an illustrious vernacular in the Italian area.

The results of the analysis of De vulgari eloquentia are summarized in the following table: 
Table 1. The occurrence of cursus in De vulgari eloquentia

\begin{tabular}{|l|l|l|}
\hline & Frequency & $\% \%$ \\
\hline Cursus planus & 142 & $30.0 \%$ \\
\hline Cursus trispondaicus & 36 & $7.6 \%$ \\
\hline Cursus velox & 98 & $20.7 \%$ \\
\hline Cursus tardus & 65 & $13.7 \%$ \\
\hline Miscellanea & 133 & $28.1 \%$ \\
\hline Total & 474 & $100.0 \%$ \\
\hline
\end{tabular}

The results of the analysis show that the percentage of the cursus in this sample is $71.9 \%$, there, cursus planus (30.0\%) predominates, for example as in natura permittit, or rationem portare. Next most frequent, by occurrence, is cursus velox (20.7\%), for example avidissimi speculantur, or memorabili castigavit, followed by cursus tardus (13.7\%), for example esse flexibile, pauci perveniunt, and finally cursus trispondaicus (7.6\%), tantum sensuale, and ipsum naturantem.

In my research I observed also the occurrence of cursus in the given sample by chapters, the summary of the analysis is in the following table:

Table 2. The occurrence of cursus (C.) in De vulgari eloquentia in different chapters

\begin{tabular}{|l|l|l|l|l|l|l|}
\hline & C. planus & C. trispondaicus & C. velox & C. tardus & Miscellanea & Total \\
\hline $1 . \mathrm{I}$ & 9 & 2 & 9 & 7 & 3 & 30 \\
\hline $1 . \mathrm{II}$ & 15 & 3 & 5 & 10 & 18 & 51 \\
\hline $1 . \mathrm{III}$ & 6 & 2 & 5 & 4 & 5 & 22 \\
\hline $1 . \mathrm{IV}$ & 14 & 3 & 7 & 9 & 17 & 50 \\
\hline $1 . \mathrm{V}$ & 9 & 1 & 3 & 4 & 6 & 23 \\
\hline $1 . \mathrm{VI}$ & 16 & 1 & 10 & 2 & 12 & 41 \\
\hline $1 . \mathrm{VII}$ & 21 & 5 & 18 & 12 & 10 & 66 \\
\hline $1 . \mathrm{VIII}$ & 13 & 5 & 15 & 2 & 11 & 46 \\
\hline $1 . \mathrm{IX}$ & 25 & 7 & 13 & 9 & 23 & 77 \\
\hline $1 . \mathrm{X}$ & 14 & 7 & 13 & 6 & 28 & 68 \\
\hline Total & 142 & 36 & 98 & 65 & 133 & 474 \\
\hline
\end{tabular}


Table 3. The occurrence of cursus in De vulgari eloquentia in different chapters (\%\%)

\begin{tabular}{|l|l|l|l|l|l|}
\hline & C. planus & C. trispondaicus & C. velox & C. tardus & Miscellanea \\
\hline $1 . \mathrm{I}$ & $30.0 \%$ & $6.7 \%$ & $30.0 \%$ & $23.3 \%$ & $10.0 \%$ \\
\hline $1 . \mathrm{II}$ & $29.4 \%$ & $5.9 \%$ & $9.8 \%$ & $19.6 \%$ & $35.3 \%$ \\
\hline $1 . \mathrm{III}$ & $27.3 \%$ & $9.1 \%$ & $22.7 \%$ & $18.2 \%$ & $22.7 \%$ \\
\hline $1 . \mathrm{IV}$ & $28.0 \%$ & $6.0 \%$ & $14.0 \%$ & $18.0 \%$ & $34.0 \%$ \\
\hline $1 . \mathrm{V}$ & $39.1 \%$ & $4.3 \%$ & $13.0 \%$ & $17.4 \%$ & $26.1 \%$ \\
\hline $1 . \mathrm{VI}$ & $39.0 \%$ & $2.4 \%$ & $24.4 \%$ & $4.9 \%$ & $29.3 \%$ \\
\hline $1 . \mathrm{VII}$ & $31.8 \%$ & $7.6 \%$ & $27.3 \%$ & $18.2 \%$ & $15.2 \%$ \\
\hline $1 . \mathrm{VIII}$ & $28.3 \%$ & $10.9 \%$ & $32.6 \%$ & $4.3 \%$ & $23.9 \%$ \\
\hline $1 . \mathrm{IX}$ & $32.5 \%$ & $9.1 \%$ & $16.9 \%$ & $11.7 \%$ & $29.9 \%$ \\
\hline $1 . \mathrm{X}$ & $20.6 \%$ & $10.3 \%$ & $19.1 \%$ & $8.8 \%$ & $41.2 \%$ \\
\hline Total & $30.0 \%$ & $7.6 \%$ & $20.7 \%$ & $13.7 \%$ & $28.1 \%$ \\
\hline
\end{tabular}

If we take a closer look, we can see the accumulation of cursus velox in chapters I, VII, VIII - where the average percentage of cursus velox in this sample is $20.7 \%$, the proportion of these in chapter I is $30.0 \%$, in chapter VII $27.3 \%$ and in chapter VIII 32.6\%. In the first chapter of De vulgari eloquentia Dante claims that he is going to discuss the theory of eloquence in vernacular and that vernacular language is natural, not artificial, and therefore more noble. In chapter VII he describes the building of the Tower of Babel and the separation of languages because of the impudence demonstrated by humankind. In chapter VIII Dante compiles a map of the geographical positions of the languages he knows dividing the European territory into three parts, with southern Europe again divided in three: oc language, oil language and si language. It can be said that those three chapters (introduction and intention to discuss the more noble kind of language, the separation of language into different idioms, composing a map of the geographical positions of the languages) are all very relevant in the first book of De vulgari eloquentia. Also, in chapter VIII the percentage of cursus trispondaicus is the highest (10.9\%), while the average is 7.6\%. In chapter $\mathrm{V}$ we can see the highest percentage of cursus planus (39.1\%) and at the same time relatively low percentage of cursus velox (13.0\%). We can see the accumulation of cursus tardus in chapter I (23.3\%, while the average percentage is 13.7) and the lowest percentage of cursus tardus is in chapter VIII (only 4.3\%).

De Monarchia (or Monarchia) is a treatise on the relationship between secular authority (represented by the Holy Roman Emperor) and religious authority (represented by the Pope). There are many opinions about the date 
of composition of this work which refer the years between 1307-1308 and 1321 (the death of Dante) (Malato 1999: 886). The work is composed of three books, in the first of which Dante affirms the need for a universal monarchy.

The data of the cursus in De Monarchia are summarized in the following table:

Table 4. The occurrence of cursus in De Monarchia

\begin{tabular}{|l|l|l|}
\hline & Frequency & $\% \%$ \\
\hline Cursus planus & 82 & $23.6 \%$ \\
\hline Cursus trispondaicus & 28 & $8.0 \%$ \\
\hline Cursus velox & 54 & $15.5 \%$ \\
\hline Cursus tardus & 50 & $14.4 \%$ \\
\hline Miscellanea & 134 & $38.5 \%$ \\
\hline Total & 348 & $100.0 \%$ \\
\hline
\end{tabular}

The results of the analysis show that the percentage of the cursus in this sample is $61.5 \%$, there, in turn, cursus planus $(23.6 \%)$ is the most used, for example interesse videtur, and esse producit. The second most frequent form is cursus velox (15.5\%), for example naturaliter principari, hominum salutabat, then cursus tardus (14,4\%), for example intellectus possibilis, ipse perficitur, and the last in frequency is cursus trispondaicus (8.0\%), for example unam civitatem, esse animatum.

The occurrence of cursus in De Monarchia was studied by chapters too; the summary of the data is given in the following table:

Table 5. The occurrence of cursus in De Monarchia in different chapters

\begin{tabular}{|l|l|l|l|l|l|l|}
\hline & C. planus & C. trispondaicus & C. velox & C. tardus & Miscellanea & Total \\
\hline $1 . \mathrm{I}$ & 8 & 0 & 7 & 9 & 5 & 29 \\
\hline $1 . \mathrm{II}$ & 8 & 3 & 7 & 5 & 19 & 42 \\
\hline $1 . \mathrm{III}$ & 14 & 4 & 9 & 8 & 37 & 72 \\
\hline $1 . \mathrm{IV}$ & 6 & 3 & 6 & 5 & 11 & 31 \\
\hline $1 . \mathrm{V}$ & 13 & 3 & 12 & 9 & 26 & 63 \\
\hline $1 . \mathrm{VI}$ & 5 & 4 & 0 & 4 & 9 & 22 \\
\hline 1. VII & 5 & 1 & 1 & 3 & 5 & 15 \\
\hline 1. VIII & 8 & 4 & 6 & 0 & 7 & 25 \\
\hline $1 . \mathrm{IX}$ & 9 & 4 & 3 & 0 & 7 & 23 \\
\hline $1 . \mathrm{X}$ & 6 & 2 & 3 & 7 & 8 & 26 \\
\hline Total & 82 & 28 & 54 & 50 & 134 & 348 \\
\hline
\end{tabular}


Table 6. The occurrence of cursus in De Monarchia in different chapters (\%\%)

\begin{tabular}{|l|l|l|l|l|l|}
\hline & C. planus & C. trispondaicus & C. velox & C. tardus & Miscellanea \\
\hline $1 . \mathrm{I}$ & $27.6 \%$ & $0.0 \%$ & $24.1 \%$ & $31.0 \%$ & $17.2 \%$ \\
\hline $1 . \mathrm{II}$ & $19.0 \%$ & $7.1 \%$ & $16.7 \%$ & $11.9 \%$ & $45.2 \%$ \\
\hline $1 . \mathrm{III}$ & $19.4 \%$ & $5.6 \%$ & $12.5 \%$ & $11.1 \%$ & $51.4 \%$ \\
\hline $1 . \mathrm{IV}$ & $19.4 \%$ & $9.7 \%$ & $19.4 \%$ & $16.1 \%$ & $35.5 \%$ \\
\hline $1 . \mathrm{V}$ & $20.6 \%$ & $4.8 \%$ & $19.0 \%$ & $14.3 \%$ & $41.3 \%$ \\
\hline $1 . \mathrm{VI}$ & $22.7 \%$ & $18.2 \%$ & $0.0 \%$ & $18.2 \%$ & $40.9 \%$ \\
\hline $1 . \mathrm{VII}$ & $33.3 \%$ & $6.7 \%$ & $6.7 \%$ & $20.0 \%$ & $33.3 \%$ \\
\hline $1 . \mathrm{VIII}$ & $32.0 \%$ & $16.0 \%$ & $24.0 \%$ & $0.0 \%$ & $28.0 \%$ \\
\hline $1 . \mathrm{IX}$ & $39.1 \%$ & $17.4 \%$ & $13.0 \%$ & $0.0 \%$ & $30.4 \%$ \\
\hline $1 . \mathrm{X}$ & $23.1 \%$ & $7.7 \%$ & $11.5 \%$ & $26.9 \%$ & $30.8 \%$ \\
\hline Total & $23.6 \%$ & $8.0 \%$ & $15.5 \%$ & $14.4 \%$ & $38.5 \%$ \\
\hline
\end{tabular}

Closer study reveals the accumulation of cursus velox in chapters I (24.1\%) and VIII (24.0\%), while average percentage of cursus velox in this sample is $15.5 \%$. Chapter I is a kind of introduction to the whole book and in chapter VIII Dante speaks about God: men are made in the image of God, but God is one. The first chapter also has the highest percentage of cursus tardus (31.0\%). On the contrary, in chapter VIII the cursus tardus does not occur at all, the same stands for chapter IX (also 0.0\%). The percentage of cursus planus is highest in chapter IX (39.1\%) and cursus trispondaicus accumulates in chapters VI (18.2\%), VIII $(16.0 \%)$ and IX (17.4\%) - the average percentage of trispondaicus is $8.0 \%$. The analysis of this sample of De Monarchia does not allow us to conclude that cursus velox accumulates in more relevant chapters, or that it has some other semantic connections. In this case, further analysis would be needed.

The data of De vulgari eloquentia and De Monarchia are juxtaposed in the following table:

Table 7. The occurrence of cursus in De vulgari eloquentia and in De Monarchia

\begin{tabular}{|l|l|l|}
\hline & Frequency & $\% \%$ \\
\hline Cursus planus & 224 & $27.3 \%$ \\
\hline Cursus trispondaicus & 64 & $7.8 \%$ \\
\hline Cursus velox & 152 & $18.5 \%$ \\
\hline Cursus tardus & 115 & $14.0 \%$ \\
\hline Miscellanea & 267 & $32.5 \%$ \\
\hline Total & 822 & $100.0 \%$ \\
\hline
\end{tabular}




\subsection{The occurrence of cursus in Dante's Convivio.}

Although the use of cursus was more popular in Latin prose, they can also be found elsewhere, including Italian prose. There are many opinions about whether and how much Dante used cursus in his Italian books, since for that purpose Dante's Latin books have been studied more systematically ${ }^{6}$. According to some authors, Dante was certainly familiar with the rules of cursus, and seemed to follow them where he found appropriate (Rajna 1932: 86).

Convivio is a work written between 1304 and 1307. This unfinished work of Dante consists of four trattati (books): a prefatory one, plus three books, each of which includes a canzone (long lyrical poem) and a prose allegorical interpretation of, or commentary on the poem that takes us in numerous thematic directions. The Convivio is a kind of vernacular encyclopaedia of the knowledge of Dante's time. It touches on many areas of learning, not only philosophy but also politics, linguistics, science and history (Malato 1995: 864-865). Book 1 explains why a book like the Convivio is needed and why Dante is writing it in the vernacular instead of Latin. Book 2 discusses allegory and Lady Philosophy (in connection with the poem Voi che 'ntendendo il terzo ciel movete), and also treats an astronomical theme (number and nature of the heavens) and angeology.

The results of the analysis of Convivio (parts I and II) are summarized in the following tables, where the distinction is made between part one and part two:

Table 8. The occurrence of cursus in Convivio part I

\begin{tabular}{|l|l|l|}
\hline Convivio part I & Frequency & $\% \%$ \\
\hline Cursus planus & 352 & $30.8 \%$ \\
\hline Cursus trispondaicus & 220 & $19.2 \%$ \\
\hline Cursus velox & 121 & $10.6 \%$ \\
\hline Cursus tardus & 49 & $4.3 \%$ \\
\hline Miscellanea & 401 & $35.1 \%$ \\
\hline Total & 1143 & $100.0 \%$ \\
\hline
\end{tabular}

6 See Malato 1999 who studies the regular use of cursuses in Dante Alihieri's books De vulgari eloquentia, Monarchia, Questio de Aqua et Terra and especially in Epistolae. 
Table 9. The occurrence of cursus in Convivio part II

\begin{tabular}{|l|l|l|}
\hline Convivio part II & Frequency & $\% \%$ \\
\hline Cursus planus & 487 & $29.2 \%$ \\
\hline Cursus trispondaicus & 284 & $17.0 \%$ \\
\hline Cursus velox & 161 & $9.7 \%$ \\
\hline Cursus tardus & 75 & $4.5 \%$ \\
\hline Miscellanea & 660 & $39.6 \%$ \\
\hline Total & 1667 & $100.0 \%$ \\
\hline
\end{tabular}

Table 10. The occurrence of cursus in Convivio part I and II

\begin{tabular}{|l|l|l|}
\hline Convivio part I and II & Frequency & $\% \%$ \\
\hline Cursus planus & 839 & $29.9 \%$ \\
\hline Cursus trispondaicus & 504 & $17.9 \%$ \\
\hline Cursus velox & 282 & $10.0 \%$ \\
\hline Cursus tardus & 124 & $4.4 \%$ \\
\hline Miscellanea & 1061 & $37.8 \%$ \\
\hline Total & 2810 & $100.0 \%$ \\
\hline
\end{tabular}

The analysis revealed that the percentage of the cursus in Convivio part one is approximately $65 \%$ and in part two approximately $60 \%$, the most frequent form is cursus planus with the incidence of approximately $30 \%$, for example solamente privato, and alcuno difetto. In both parts of Convivio the next in frequency is cursus trispondaicus (17.9\%), for example prima partorita, servo conoscente, then cursus velox (10.0\%), for example essere al migliore, numero regolato, and finally, cursus tardus has the smallest frequency (4.4\%), for example essa medesima, quinta e ultima.

Summary of the analysis of the occurrence of cursus in part one and two by chapters in part one is showed in the following table: 
Table 11. The occurrence of cursus in Convivio part I in different chapters

\begin{tabular}{|l|l|l|l|l|l|l|}
\hline & C. planus & C. trispondaicus & C. velox & C. tardus & Miscellanea & Total \\
\hline $1 . \mathrm{I}$ & 32 & 18 & 12 & 6 & 37 & 105 \\
\hline $1 . \mathrm{II}$ & 33 & 24 & 11 & 5 & 26 & 99 \\
\hline $1 . \mathrm{III}$ & 22 & 16 & 7 & 1 & 27 & 73 \\
\hline $1 . \mathrm{IV}$ & 25 & 15 & 13 & 3 & 28 & 84 \\
\hline $1 . \mathrm{V}$ & 30 & 23 & 8 & 2 & 26 & 89 \\
\hline $1 . \mathrm{VI}$ & 16 & 11 & 12 & 5 & 18 & 62 \\
\hline $1 . \mathrm{VII}$ & 28 & 28 & 8 & 2 & 27 & 93 \\
\hline $1 . \mathrm{VIII}$ & 37 & 13 & 12 & 2 & 46 & 110 \\
\hline $1 . \mathrm{IX}$ & 23 & 11 & 4 & 5 & 17 & 60 \\
\hline $1 . \mathrm{X}$ & 28 & 19 & 6 & 4 & 26 & 83 \\
\hline $1 . \mathrm{XI}$ & 34 & 23 & 8 & 7 & 57 & 129 \\
\hline $1 . \mathrm{XII}$ & 23 & 11 & 9 & 5 & 38 & 86 \\
\hline $1 . \mathrm{XIII}$ & 21 & 8 & 11 & 2 & 28 & 70 \\
\hline Total & 352 & 220 & 121 & 49 & 401 & 1143 \\
\hline
\end{tabular}

Table 12. The occurrence of cursus in Convivio part I in different chapters (\%\%)

\begin{tabular}{|l|l|l|l|l|l|}
\hline & C. planus & C. trispondaicus & C. velox & C. tardus & Miscellanea \\
\hline $1 . \mathrm{I}$ & $30.5 \%$ & $17.1 \%$ & $11.4 \%$ & $5.7 \%$ & $35.2 \%$ \\
\hline $1 . \mathrm{II}$ & $33.3 \%$ & $24.2 \%$ & $11.1 \%$ & $5.1 \%$ & $26.3 \%$ \\
\hline $1 . \mathrm{III}$ & $30.1 \%$ & $21.9 \%$ & $9.6 \%$ & $1.4 \%$ & $37.0 \%$ \\
\hline $1 . \mathrm{IV}$ & $29.8 \%$ & $17.9 \%$ & $15.5 \%$ & $3.6 \%$ & $33.3 \%$ \\
\hline $1 . \mathrm{V}$ & $33.7 \%$ & $25.8 \%$ & $9.0 \%$ & $2.2 \%$ & $29.2 \%$ \\
\hline $1 . \mathrm{VI}$ & $25.8 \%$ & $17.7 \%$ & $19.4 \%$ & $8.1 \%$ & $29.0 \%$ \\
\hline $1 . \mathrm{VII}$ & $30.1 \%$ & $30.1 \%$ & $8.6 \%$ & $2.2 \%$ & $29.0 \%$ \\
\hline $1 . \mathrm{VIII}$ & $33.6 \%$ & $11.8 \%$ & $10.9 \%$ & $1.8 \%$ & $41.8 \%$ \\
\hline $1 . \mathrm{IX}$ & $38.3 \%$ & $18.3 \%$ & $6.7 \%$ & $8.3 \%$ & $28.3 \%$ \\
\hline $1 . \mathrm{X}$ & $33.7 \%$ & $22.9 \%$ & $7.2 \%$ & $4.8 \%$ & $31.3 \%$ \\
\hline $1 . \mathrm{XI}$ & $26.4 \%$ & $17.8 \%$ & $6.2 \%$ & $5.4 \%$ & $44.3 \%$ \\
\hline $1 . \mathrm{XII}$ & $26.7 \%$ & $12.8 \%$ & $10.5 \%$ & $5.8 \%$ & $44.2 \%$ \\
\hline $1 . \mathrm{XIII}$ & $30.0 \%$ & $11.4 \%$ & $15.7 \%$ & $2.9 \%$ & $40.0 \%$ \\
\hline Total & $30.8 \%$ & $19.2 \%$ & $10.6 \%$ & $4.3 \%$ & $35.1 \%$ \\
\hline
\end{tabular}


If we take a closer look at the occurrence of cursus velox and cursus tardus in part one, we can see their abundance in one chapter - VI (19.4\% and $8.1 \%)$. It is much higher than the average frequency on these two types of cursus (10.6\% for cursus velox and $4.3 \%$ for cursus tardus). In chapters V-VII Dante explains the first reason for using vernacular and not Latin in Convivio. Throughout these three chapters the percentage of all types of cursus is also high - ca $71 \%$. In chapter XIII (last chapter of book I) the percentage of cursus velox in also high $-15.7 \%$, but the percentage of tardus in quite average $-2.9 \%$. In the last chapter of book I Dante exalts the new language and predicts a future success to lingua volgare. Explaining the reasons of using vernacular instead of Latin and predicting a future success to vernacular are quite important parts in the first book of Convivio and the abundance of cursus velox in those chapters may not be incidental ${ }^{7}$.

Book II is a kind of comment on the first poem in Convivio (Voi che 'ntendendo il terzo ciel movete). Summary of the analysis in part two could be seen in the following table:

Table 13. The occurrence of cursus in Convivio part II in different chapters

\begin{tabular}{|l|l|l|l|l|l|l|}
\hline & C. planus & C. trispondaicus & C. velox & C. tardus & Miscellanea & Total \\
\hline 2.I & 27 & 19 & 9 & 2 & 41 & 98 \\
\hline 2. II & 21 & 9 & 4 & 3 & 22 & 59 \\
\hline 2. III & 12 & 14 & 3 & 3 & 21 & 53 \\
\hline 2. IV & 33 & 12 & 3 & 4 & 45 & 97 \\
\hline 2. V & 32 & 19 & 15 & 5 & 39 & 110 \\
\hline 2.VI & 41 & 31 & 18 & 5 & 48 & 143 \\
\hline 2.VII & 27 & 21 & 10 & 2 & 48 & 108 \\
\hline 2.VIII & 26 & 18 & 10 & 5 & 36 & 95 \\
\hline 2.IX & 29 & 15 & 9 & 6 & 43 & 102 \\
\hline 2.X & 26 & 12 & 6 & 1 & 29 & 74 \\
\hline 2.XI & 30 & 16 & 9 & 3 & 33 & 91 \\
\hline 2.XII & 24 & 13 & 7 & 1 & 20 & 65 \\
\hline 2.XIII & 27 & 10 & 11 & 0 & 25 & 73 \\
\hline 2.XIV & 62 & 42 & 21 & 19 & 85 & 229 \\
\hline 2.XV & 38 & 20 & 15 & 14 & 76 & 163 \\
\hline 2.XVI & 32 & 13 & 11 & 2 & 49 & 107 \\
\hline Total & 487 & 284 & 161 & 75 & 660 & 1667 \\
\hline & & & & & \\
\hline
\end{tabular}

7 The analysis of Dante's other Italian prose book, Vita Nuova, also showed an accrual of cursus velox in certain relevant chapters (Mikkel 2011: 708). 
Table 14. The occurrence of cursus in Convivio part II in different chapters (\%\%)

\begin{tabular}{|l|l|l|l|l|l|}
\hline & C. planus & C.s trispondaicus & C. velox & C. tardus & Miscellanea \\
\hline $2 . \mathrm{I}$ & $27.6 \%$ & $19.4 \%$ & $9.2 \%$ & $2.0 \%$ & $41.8 \%$ \\
\hline $2 . \mathrm{II}$ & $35.6 \%$ & $15.3 \%$ & $6.8 \%$ & $5.1 \%$ & $37.3 \%$ \\
\hline $2 . \mathrm{III}$ & $22.6 \%$ & $26.4 \%$ & $5.7 \%$ & $5.7 \%$ & $39.6 \%$ \\
\hline $2 . \mathrm{IV}$ & $34.0 \%$ & $12.4 \%$ & $3.1 \%$ & $4.1 \%$ & $46.4 \%$ \\
\hline $2 . \mathrm{V}$ & $29.1 \%$ & $17.3 \%$ & $13.6 \%$ & $4.5 \%$ & $35.5 \%$ \\
\hline $2 . \mathrm{VI}$ & $28.7 \%$ & $21.7 \%$ & $12.6 \%$ & $3.5 \%$ & $33.6 \%$ \\
\hline $2 . \mathrm{VII}$ & $25.0 \%$ & $19.4 \%$ & $9.3 \%$ & $1.9 \%$ & $44.4 \%$ \\
\hline $2 . \mathrm{VIII}$ & $27.4 \%$ & $18.9 \%$ & $10.5 \%$ & $5.3 \%$ & $37.9 \%$ \\
\hline $2 . \mathrm{IX}$ & $28.4 \%$ & $14.7 \%$ & $8.8 \%$ & $5.9 \%$ & $42.2 \%$ \\
\hline $2 . \mathrm{X}$ & $35.1 \%$ & $16.2 \%$ & $8.1 \%$ & $1.4 \%$ & $39.2 \%$ \\
\hline $2 . \mathrm{XI}$ & $33.0 \%$ & $17.6 \%$ & $9.9 \%$ & $3.3 \%$ & $36.3 \%$ \\
\hline $2 . \mathrm{XII}$ & $36.9 \%$ & $20.0 \%$ & $10.8 \%$ & $1.5 \%$ & $30.8 \%$ \\
\hline $2 . \mathrm{XIII}$ & $37.0 \%$ & $13.7 \%$ & $15.1 \%$ & $0.0 \%$ & $34.2 \%$ \\
\hline $2 . \mathrm{XIV}$ & $27.1 \%$ & $18.3 \%$ & $9.2 \%$ & $8.3 \%$ & $37.1 \%$ \\
\hline $2 . \mathrm{XV}$ & $23.3 \%$ & $12.3 \%$ & $9.2 \%$ & $8.6 \%$ & $46.6 \%$ \\
\hline $2 . \mathrm{XVI}$ & $29.9 \%$ & $12.1 \%$ & $10.3 \%$ & $1.9 \%$ & $45.8 \%$ \\
\hline Total & $29.2 \%$ & $17.0 \%$ & $9.7 \%$ & $4.5 \%$ & $39.6 \%$ \\
\hline & & & & & \\
\hline
\end{tabular}

In the book two of Convivio the incidence of all types of cursus is the highest in chapter XII - 69.2\%, while the occurrence of cursus velox is highest in chapter XIII (15.1\%). An average use of cursus velox in book two is $9.7 \%$. In chapter XIII the percentage of cursus tardus is $0 \%$ (which is also significant) and the percentage of all types of cursus is $65.8 \%$. Cursus tardus is used more frequently in chapters XIV (8.3\%) and XV (8.6\%), while the average use of cursus in this book is $4.5 \%$. We should particularly mention the higher occurrence of cursus velox and tardus in the last chapters of this book. 


\subsection{Comparison of Latin and Italian texts}

The following table juxtaposes the data of Convivio, De vulgari eloquentia and Monarchia:

Table 15. The comparison of cursus in Convivio, De vulgari eloquentia and Monarchia

\begin{tabular}{|l|l|l|l|}
\hline & Convivio & DVE & Monarchia \\
\hline Cursus planus & $29.9 \%$ & $30.0 \%$ & $23.6 \%$ \\
\hline cursus trispondaicus & $17.9 \%$ & $7.6 \%$ & $8.0 \%$ \\
\hline cursus velox & $10.0 \%$ & $20.7 \%$ & $15.5 \%$ \\
\hline cursus tardus & $4.4 \%$ & $13.7 \%$ & $14.4 \%$ \\
\hline Miscellanea & $37.7 \%$ & $28.1 \%$ & $38.5 \%$ \\
\hline Total & $100.0 \%$ & $100.0 \%$ & $100.0 \%$ \\
\hline
\end{tabular}

In table 16 we see compare the results of Latin and Italian samples:

Table 16. A comparison of cursus in Latin and Italian samples

\begin{tabular}{|l|l|l|}
\hline & Convivio & DVE+Monarchia \\
\hline Cursus planus & $29.9 \%$ & $27.3 \%$ \\
\hline Cursus trispondaicus & $17.9 \%$ & $7.8 \%$ \\
\hline Cursus velox & $10.0 \%$ & $18.5 \%$ \\
\hline Cursus tardus & $4.4 \%$ & $14.0 \%$ \\
\hline Miscellanea & $37.7 \%$ & $32.5 \%$ \\
\hline Total & $100.0 \%$ & $100.0 \%$ \\
\hline
\end{tabular}

The comparison shows us that in Latin samples the percentage of cursus is $67.5 \%$ and in Convivio $62.3 \%$. As we can see, there is no significant difference between these two samples. The biggest difference concerns the use of cursus velox and tardus: in Latin samples the percentage of cursus velox is $18.5 \%$, while in Convivio $10.0 \%$. The percentage of cursus tardus in Convivio is $4.4 \%$ and in Latin works $14.0 \%$. It can be said that the prosody of both language influences the use of cursus. In Latin, word stress may be on the penult or the third syllable from the end, and cursus velox comprises words with such stresses. Many vernacular words, instead, have the stress on the penultimate syllable, and in Convivio Dante used mostly cursus planus and trispondaicus which comprise words with stress on the penultimate syllable. In Latin samples, the percentage of cursus planus is quite similar to the result of Convivio - $27.3 \%$ in Latin and $29.9 \%$ in vernacular. But the use of cursus trispondaicus in Latin works is low, only $7.8 \%$, as opposed to $17.9 \%$ in Convivio. 


\section{Conclusion}

Based on this analysis, it can be said that Dante is not indifferent towards prose rhythm, and that the cursus appear in his Latin works, as well as in his works in vernacular. The importance of the rhythmical endings of sentences in Dante's prose can also be seen from the use of cursus velox. In Latin prose in general, cursus velox was the most popular and most often used. It was also considered as one of the most elegant cursus and used above all at the end of the sentences as well as, quite often, at the end of the book. Cursus tardus was also used more frequently in Latin prose than in Italian, probably for the prosodic reasons. Furthermore, the higher use of tardus in some parts of Dante's vernacular prose may indicate the importance of rhythm for Dante. The distribution of cursus is not homogeneous in different parts of his works. We can see, for example, the preference of cursus velox in some parts, and the absence of some type of cursus in several chapter (thus, in the sample of De Monarchia there are no cursus tardus at all in the chapters VIII and IX and no cursus velox in chapter VI). Cursus planus is used more or less equally in every part of his books, both in Latin and in vernacular.

The analysis of these samples indicates the accrual of cursus velox in the first chapters (in De vulgari eloquentia and in De Monarchia) or in the final chapters of the book (in both books of Convivio). In the final chapters of the second book of Convivio we can also see the higher use of cursus tardus. Analysing the sample of De vulgari eloquentia, we can point out an accumulation of cursus velox in some more relevant chapters in this book, the same can be said about the first book of Convivio.

In order to say more about the use of cursus in Dante, it would be necessary to study the works of some other contemporaries of Dante, and to compare the results. We hope it will be done in further research.

\section{References}

Alighieri, Dante 1993. Tutte le opere. Divina Commedia, Vita Nuova, Rime, Convivio, De vulgari eloquentia, Monarchia, Egloghe, Epistole, Quaestio de aqua et de terra. Roma: Grandi Tascabili Economici Newton.

Aili, Hans 1979. The Prose Rhythm of Sallust and Livy. Stockholm: Almquist \& Wiksell International.

Clark, Albert Curtius 1910. The cursus in Mediaeval and Vulgar Latin. Oxford: Clarendon Press. 
Grillo, Luca 2015. Cicero's De Provinciis Consularibus Oratio. Oxford: University Press.

Janson, Tore 1975. Prose Rhythm in Medieval Latin from the $9^{\text {th }}$ to the $13^{\text {th }}$ Century. Stockholm: Almquist \& Wiksell International.

Lindholm, Gudrun 1963. Studien zum Mittellateinischen Prosarhythmus. Seine Entwicklung und sein Abklingen in der Briefliteratur Italiens. Stockholm: Almquist \& Wiksell International.

Malato, Enrico 1999. Dante. In: Malato, Enrico (ed.), Storia della letteratura italiana. Vol. I: Dalle origini a Dante. Roma: Salerno, 773-1052.

Menichetti, Aldo 1993. Metrica italiana. Fondamenti metrici, prosodia, rima. Padova: Editrice Antenore.

Migliorini, Bruno; Tagliavini, Carlo; Fiorelli, Piero Dizionario d'ortografia e di pronunzia. http://www.dizionario.rai.it/

Mikkel, Annika 2011. Medieval cursus in Italian prose by example of Dante Alighieri. In: Interlitteraria 16(2), 698-711.

Norberg, Dag 1968. Manuel pratique de latin médiéval. Paris: Picard.

Norberg, Dag 2014. Introduction to the Study of Medieval Latin Versification. Washington: Catholic University of America Press.

Oberhelman, Steven M.; Hall, Ralph G. 1984. A New Statistical Analysis of Accentual Prose Rhythms in Imperial Latin Authors. In: Classical Philology 79, 114-130.

Oberhelman, Steven M.; Hall, Ralph G. 1985. Meter in Accentual Clausulae of Late Imperial Latin Prose. In: Classical Philology 80, 214-227.

Rajna, Pio 1932. Per il "cursus” medievale e per Dante. In: Studi di filologia italiana. Bulletino della R. Accademia della Crusca. Vol. III. Firenze: G.C. Sansoni.

Stecker, Karl 1999. Introduction to Medieval Latin. Zürich: Weidmann.

Tunberg, Terence O. 1996. Prose styles and cursus. In: Mantello, Frank A. C.; Rigg, Arthur G. (eds.), Medieval Latin. Washington: The Catholic University of American Press, 111-121. 